\title{
Hospital networks: How to make them work in Belgium? Facilitators and barriers of different governance models
}

Objectives: This study aims to identify the facilitators and barriers to governance models of hospital collaborations. The country-specific characteristics of the Belgian healthcare system and legislation are taken into account.

Methods: A case study was carried out in six Belgian hospital collaborations. Different types of governance models were selected: two health systems, two participant-governed networks, and two lead-organization-governed networks. Within these collaborations, 43 people were interviewed.

Results: All structures have both advantages and disadvantages. It is important that the governance model fits the network. However, structural, procedural, and especially contextual factors also affect the collaborations, such as alignment of hospitals' and professionals' goals, competition, distance, level of integrated care, time needed for decision-making, and legal and financial incentives.

Conclusion: The fit between the governance model and the collaboration can facilitate the functioning of a collaboration. The main barriers we identified are contextual factors. The Belgian government needs to play a major role in facilitating collaboration.

Keywords: hospital networks, governance, collaboration, policy, management

This study has been conducted according in accordance with the Guideline for Good Clinical Practice and the Declaration of Helsinki for Medical Research Involving Human Subjects. 


\section{Introduction}

The number of collaborations between Belgian hospitals has increased over the last decade. Following the new regulation guidelines in the action plan of the Minister of Social Affairs and Public Health (April 2015), ${ }^{1}$ hospitals must become part of a larger care collaboration, where they will need to join forces to better coordinate and integrate patient care across hospital boundaries and enhance task distribution. Examples of such a collaboration and task distribution include a concentration of highly-specialized services, such as rare cancer treatment, in reference centres, ${ }^{2,3}$ or the rationalization of general care services such as maternity services.

Following the current Belgian Hospital Act three types of collaboration between hospitals exist: an association (collaboration between two or more hospitals aimed at the joint exploitation of one or more care programs, hospital departments, or functions), a group (collaboration between hospitals with agreements on task distribution and complementarity on the level of services, disciplines, and equipment, in order to meet the needs of the population and to improve quality of care) and a merger (the most far-reaching form of hospital collaboration since it involves two or more hospitals joining as one hospital with a single administrator). Each type of collaboration is strictly defined with very strict rules allowing only a low level of flexibility (See also Table 1). ${ }^{4}$ The basic principles of the action plan were operationalized in a vision statement of the minister in October $2016,{ }^{5}$ and the first version of the new legislation is being discussed at the time of writing. New governance models are needed to support these hospital collaborations, as the current traditional forms of collaboration are no longer sufficient, and several other forms of collaboration are emerging in a bottom-up matter. ${ }^{4}$ However, the way in which collaborations tend to develop in a country depends not only on the governance in interhospital collaborations; it is the intertwined role of governance, processes, and structures that drives a collaboration. External factors, such as the macrolevel mechanisms used to coordinate the healthcare system, also affect the governance of hospitals and hospital 
collaborations. ${ }^{6}$ This study aims to identify the facilitators and barriers to the governance of hospital collaborations. The country-specific characteristics of the Belgian context are taken into account.

\section{Method}

\section{Case selection}

Six Belgian hospital collaborations were investigated. The collaborations were selected based on the type of governance structure, according to the classification of Provan and Kenis ${ }^{7}$ - that is, a health system, a participant-governed network, or a lead-organization-governed network. ${ }^{7}$ A 'lead organization' structure is characterized by a dominant organization in the network that takes responsibility for the governance. In a 'participant-governed' network structure, there is no separate governance entity, and governance remains the responsibility of each organization

in the network. ${ }^{7}$ A health system is a more integrated governance structure, in which more hierarchical control is applied, meaning that a central board is in charge of overall coordination. ${ }^{8}$ The other selection criteria were region, language, size, and willingness to cooperate.

\section{Data collection}

A case-study design was selected in order to explore the barriers and facilitators of the different governance models for supporting collaboration. This design is appropriate for exploring 'how' and 'why' questions about a contemporary set of events over which the investigator has little or no control. ${ }^{9}$

Site visits were organized for each case. These included encounters with key informants, such as board members, presidents or representatives of medical councils, chief executive officers (CEOs), chief medical officers (CMOs), and network coordinators or managers. A semistructured interview guide with key questions was used. This helped to define the areas to 
be explored, but also allowed the interviewer or interviewee to diverge to pursue an idea or response in more detail. The site visits were complemented by telephone interviews (e.g., when key informants were not available during the site visit) and emails (e.g., to obtain additional information). Encounters with physician representatives and administrators were organized separately, in order to avoid social acceptance bias. Field notes were taken during the site visits, and audio recordings were made of all conversations with key informants, with the consent of the interviewees. In addition, the relevant documents, such as collaboration agreements, were consulted where possible. This gathering of multiple sources of evidence made the conclusions more accurate.

NVivo $11.0^{10}$ was used to analyse the transcribed interview data for the six Belgian cases. We coded the transcripts according to the broad themes of interest of the study and allowed in vivo codes to arise. Two researchers conducted the interviews together, so they could complete each other's information and avoid information loss.

\section{Results}

In total, 43 people were interviewed, of which 20 were CEOs, nine were representatives of medical councils, eight were CMOs, three were presidents of the board, and three were network coordinators (one physician and two nurses). Some of the participants have an intertwined role as some of the CEOs were also board members and/or network coordinators. The length of the interviews depended on the participant (e.g., first interview for the particular case) and on the interview method (e.g., face to face versus by phone). On average, the interviews lasted one hour. 


\section{Governance models in interhospital collaborations}

The following section presents the results of the interviews. In Table 2, the goals and the governance models are reported for each collaboration. Table 3 provides an overview of the facilitators and barriers, by collaboration.

Insert

Table 1. Collaboration forms in the current Belgian legislation

Table 2. Description of cases

Table 3. Facilitators and barriers

about here

\section{Barriers and facilitators}

\section{Facilitators}

Depending on the characteristics, goals, and governance model of a collaboration, different facilitators were identified. Expertise and knowledge transfer are among the main drivers to collaboration. For example, if the two lead organizations have a great deal of expertise in specific clinical domains, the credibility of the collaboration is strengthened and the number of hospitals that will want to join the collaboration may increase. Another type of expertise identified is the transmural, crossdomain experience in health systems. Expertise from different types of service providers, such as elderly care institutes, home care, psychiatric care, and general practitioners can be shared to ameliorate task distribution and improve the level of integrated care. Moreover, the well-known brand of a large collaboration can facilitate the visibility of individual organizations and their engagement as an important stakeholder in governmental decisions. 
Participants in lead organizations and health systems underline the benefits of more integrated and central governance structures. Central governance enhances the processes of decisionmaking and coordination, and creates more time for strategic choices. However, interviewees in participant-governed networks emphasize the importance of their equal decision rights, which enhance the consensus decision-making and facilitates the level of trust. Organizations maintain their autonomy, which simplifies the process of entering the collaboration.

Collaborations enable the sharing of resources and supporting services, saving costs for the participating organizations. This tends to be identified as an advantage of health systems in particular. In all cases, integrated IT systems were mentioned as a crucial resource for sharing patient information. However, this remains still a challenge.

\section{Barriers}

The various medical councils and boards in a collaboration complicate the process of decisionmaking, making it more time consuming. In lead-organization-governed network 1 , for example, there is a network board and a common medical committee. However, most decisions need the approval of the medical councils of the individual hospitals. This shows the importance of the alignment of goals between different parties and hospitals. In some cases, managers and physicians do not always agree on strategic goals, with the medical council sometimes holding back the progress of the collaboration. Moreover, because of their therapeutic freedom, physicians can choose who they collaborate with and may refer to other partners outside the collaboration.

Conflicts do not occur only between different groups of professionals, but also between different hospitals. Due to the large scale and the more centralized governance structures of health systems, small hospitals in such structures feel less involved in the process of decisionmaking. On the other hand, large hospitals sometimes feel impeded by the smaller organizations in a collaboration. In addition, more centralized governance structures make it hard for 
members to leave a collaboration. Organizations that are entering such a collaboration often fear losing their autonomy and decision-making rights. This was identified as a barrier in one health system and in the lead-organization-governed networks. Both lead organizations are therefore aiming to evolve to a participant network to equalize decision-making rights.

The complex legal and financial structures in Belgium also complicate collaboration. Due to the legislative system, which has federal and regional government aspects, the legislative regulations a collaborations are very complex. The regional authorities are responsible for all authorizations, for example, for care programs and collaborations, but these must be in line with the federal programming standards. Moreover, financial barriers also exist. The hospital budget, called the budget of financial means (BFM), is paid to the legal entity running the hospital. Although theoretically possible (via a specific Royal Decree granting a BFM directly to the hospital collaboration concerned), in practice, collaborations are currently not entitled to a BFM, even if they have their own legal entity (e.g., a not-for-profit association). This is considered an important barrier to collaboration in all cases. Although one of the cases is a notfor-profit association (with its own balance sheet), the income of the main activity of the collaboration has to be part of the balance sheet of one of the hospitals in order to obtain a BFM. There are also many problems related to the payment of medical staff and the related regulations. Physicians referring for a collaborating hospital receive no financial benefits at the moment because of the predominant fee-for-service system. ${ }^{11}$ In other words, they do not receive payments for sending a patient to another care provider, except where physicians' income is pooled and redistributed. Second, when physicians work at multiple hospitals, they may be working under different terms, as different agreements regarding the deduction of physician' fees can exist in different hospitals. Third, it is unclear whether deductions to physician' fees can be collected in a collaboration rather than at a single hospital. Fourth, physicians working in several hospitals lose their voting power in medical council elections which also restricts their possibility to be appointed in advisory boards such as the medical 
pharmaceutical committee, the committee on medical materials, etc. This restrains physicians to actively participate in the integration/networking process.

Certain collaborations also require employees to work at different hospitals. This is especially the case for more integrated systems that aim to transfer personnel from one organization in the collaboration to another, as is the case with health systems. The existing legal forms of collaboration between hospitals do not cover such flexible staff arrangements. In principle, a hospital cannot allow its own personnel to work for other hospitals in the collaboration. Leadorganization-governed network 1 , for example, solved this problem by having all employees and physicians in the collaboration be employed by the lead organization.

Another challenge is the distance between hospitals. Hospitals that provide basic care services should be located at a manageable distance from each other. This is a challenge for both of the health systems. Consequently, hospitals have begun to collaborate with other hospitals outside of the collaboration. Distance is identified as less of a problem for more specialized services. It should be noted that, in some cases, distance is not really considered a problem - such as where the equal culture and vision of collaborating organizations is seen to be more important than the distance between the hospitals.

There are also concerns related to competition. The goals and the strategies of individual organizations need to be aligned with the overall strategy of the collaboration. Competition between organizations within a network or health system can decrease the level of collaboration. Moreover, large collaborations can also become monopolies, undermining service and quality in Belgian healthcare services, as the market principle is undermined in a monopoly. Participants mentioned that the government should control competition between hospitals. 


\section{Discussion}

Depending on the goals of the collaboration and the governance model, the facilitators and barriers to collaboration differ. There is no specific governance model that suffers from many more problems than the others. On the one hand, participant-governed networks show the importance of bottom-up decision-making, which increases consensus decision-making. On the other hand, more integrated structures such as health systems have more time to focus on strategic choices. Consequently, it is important for organizations to be able to select the most appropriate governance model for their collaboration. In line with Provan and Kenis, ${ }^{7}$ our results show that the successful adoption of a given type of governance model is related to the characteristics of the network and the context in which the collaboration operates. This study shows the importance of the alignment of goals, the level of trust between the partners, the distance between organizations, the scale, and the type of goal.

Contextual factors, such as problems related to VAT, (social) legislation about transferring employees between independent organisations in a network ${ }^{4}$ and the criteria related to the authorization of a hospital such as the necessity of having a pharmacy, ${ }^{12}$ also counteract the formation of collaborations. Moreover, changes due to the sixth reform of the state in Belgium complicate the establishment of collaborations that combine different types of care because some types are financed at the regional level and others at the national level. This distribution of financing responsibility complicates integrated care initiatives such as collaborations with elderly care, psychiatric care, etc. Moreover, only licensed hospitals can be financed; at present it is not allowed to give financial resources to the collaboration. Therefore, to facilitate collaborations current legislation needs to be adapted to allow collaborations to be licensed, to receive financial resources and to appoint physicians and employees on the level of the collaboration.

A mismatch between a governance model and organizational characteristics can harm collaboration performance. ${ }^{13}$ As such, it is important that a best fit between the collaboration 
characteristics and the governance model is chosen to facilitate the collaboration. For example, there is an evolution observed in the two lead-organization-governed networks: they aim to evolve into participant-governed networks, as this structure is now more aligned with the goals of the network. It is not unusual for collaborations to evolve to other types of governance models. ${ }^{14,15}$ Nongovernance facilitators that have also been found important in this study include the sharing of resources and supporting services (which is a legal barrier at the current legislation e.g. pharmacy, see above), integrated IT systems, sharing of experience and knowledge, a well-known brand, and the alignment of goals between different parties and hospitals. Most of these facilitators relate to the structural characteristics of a collaboration. Elements of the complex governance model of collaborations - such as the different boards and medical councils and the scale of the collaboration-were reported as significant barriers. The current legislation does not motivate physicians to collaborate since they have to give up a part of their voting right and their possibility to be appointed in specific committees might be restricted. Above that, collaboration increases efficiency to a certain level, but over-large collaborations can be too complex to manage. ${ }^{16,17}$ The loss of autonomy makes it more difficult for organizations to enter an organization. Also the geographical distance between organizations is identified as an important barrier. The government should also control the way collaborations evolve and ensure that market principles are adhered to. Finally, developing trust and a relationship over time is a challenge. ${ }^{18}$ Investment in a common goal and a long-term perspective is important for collaborations. ${ }^{19}$

\section{Conclusion}

As each governance model has its advantages and disadvantages, and an evolution in governance models was observed, we conclude that a fit between governance model and the collaboration in a certain context can facilitate the functioning of the collaboration. The main barriers identified were contextual factors. In conclusion, the Belgian government plays an 
important role in facilitating collaboration and leaving room for collaborations to select their own governance model.

\section{References}

1. Beleidscel van de minister van Sociale Zaken en Volksgezondheid. Plan van Aanpak: Hervorming ziekenhuisfinanciering. 28 April 2015. http://www.vvpaz.be/Plan_van_Aanpak_Hervorming_ZHF_NL.pdf

2. Vandeurzen J. Beleidsnota 2014-2019 Welzijn, Volksgezondheid en Gezin. 2014. https://www.vlaanderen.be/nl/publicaties/detail/beleidsnota-2014-2019-welzijnvolksgezondheid-en-gezin

3. Vandeurzen J. Nieuw Vlaams ziekenhuislandschap. Focus op de patiënt. 2016. https://www.zorg-engezondheid.be/sites/default/files/atoms/files/08072016_Nota_Nieuw Vlaams Ziekenhuislandschap.pdf

4. Eeckloo K, De Regge M, De Pourcq K, Gemmel P, Callens S. Evaluatie van de wetgeving op de associatie, groepering en fusie in de context van toenemende samenwerking tussen ziekenhuizen. Tijdschrift voor Geneeskunde. 2018;73(2):90-98.

5. Beleidscel van de minister van Sociale Zaken en Volksgezondheid. Visienota inzake de hervormingen en rationalisering in de ziekenhuissector. October 2016. http://asgb.be/wpcontent/uploads/2016/10/201610241.Visienota-minister-De-Block.pdf

6. Bryson JM, Crosby BC, Stone MM. Designing and implementing cross-sector collaborations: Needed and challenging. Public Administration Review. 2015;75(5):647-63.

7. Provan K, Kenis P. Modes of network governance: Structure, management, and effectiveness. Journal of Public Administration Research and Theory. 2008;18(2):229-52.

8. Proenca E, Rosko M, Dismuke C. Service collaboration and hospital cost performance: direct and moderating effects. Medical Care. 2005;43(12):1250-8. 
9. Yin R. Case Study Research: Design and Methods. 5th ed. United States of America: SAGE Publications; 2014.

10. NVivo qualitative data analysis software. QSR International Pty Ltd Version 11; 2012. 11. Van de Voorde C, Van den Heede K, Obyn C, Quentin W, Geissler A, Wittenbecher F, Busse R, Magnussen J, Camaly O, Devriese S, Gerkens S, Misplon S, Neyt M, Mertens R. Conceptual framework for the reform of the Belgian hospital payment system. Health Services Research (HSR) Brussels: Belgian Health Care Knowledge Centre (KCE). 2014. KCE Reports 229. D/2014/10.273/68.

12. De Pourcq K, De Regge M, Callens S, Coëffé M, Van Leuven L, Gemmel P, Van den Heede K, Van de Voorde C, Eeckloo K. Governance models for hospital collaborations: Short report. Health Services Research (HSR) Brussels: Belgian Health Care Knowledge Centre (KCE). 2016. KCE Reports 277Cs. D/2016/10.273/91. https://kce.fgov.be/sites/default/files/atoms/files/KCE_277C_Governance_models_hosptial_c ollaborations_Short\%20__Report.pdf

13. Hoetker G, Mellewigt T. Choice and performance of governance mechanisms: matching alliance governance to asset type. Strategic Management Journal. 2009;30(10):1025-44.

14. Ruef M, Scott W. A multidimensional model of organizational legitimacy: Hospital survival in changing institutional environments. Administrative Science Quarterly. 1998;43(4):877-904.

15. Probandari A, Utarini A, Lindholm L, Hurtig A. Life of a partnership: The process of collaboration between the National Tuberculosis Program and the hospitals in Yogyakarta, Indonesia. Social Science \& Medicine. 2011;73(9):1386-94.

16. Huerta TR, Casebeer A, Vanderplaat M. Using networks to enhance health services delivery: Perspectives, paradoxes and propositions. Healthcare Papers. 2005;7(2):10-26. 
17. Provan KG, Lemaire RH. Core concepts and key ideas for understanding public sector organizational networks: Using research to inform scholarship and practice. Public Administration Review. 2012;72(5):638-48.

18. McGuire M. Collaborative public management: Assessing what we know and how we know it. Public administration review. 2006;66(S1):33-43.

19. Bryson JM, Crosby BC, Stone MM. The design and implementation of cross-sector collaborations: Propositions from the literature. Public administration review. 2006;66(S1):4455. 
Table 1: Collaboration forms in current Belgian legislation

\begin{tabular}{|c|c|c|c|c|}
\hline Collaboration & Legal entity & Governance structure & Decision power & Additional legal requirements \\
\hline Hospital group & $\begin{array}{l}\text { - Creation of a new legal } \\
\text { entity } \\
\text { - } \quad \text { or by contract between } \\
\text { hospitals }\end{array}$ & $\begin{array}{l}\text { - Common medical committee: } \\
\text { composed of representatives of } \\
\text { different medical councils } \\
\text { Coordination committee: composed of } \\
\text { representatives of the boards of } \\
\text { different hospitals of the group. The } \\
\text { coordination committee complies with } \\
\text { the requirements described in the } \\
\text { group agreement } \\
\text { A medical coordinator, a coordinator } \\
\text { for the nursing department and a } \\
\text { general coordinator have to be } \\
\text { appointed. }\end{array}$ & $\begin{array}{l}\text { - Approval by the coordination } \\
\text { committee of decisions regarding } \\
\text { investment, the creation of new } \\
\text { services or of new medico-technical } \\
\text { services by the hospitals of the group } \\
\text { - Authorisation depends on this approval }\end{array}$ & $\begin{array}{l}\text { - A group must comply with several } \\
\text { conditions in order to be authorised } \\
\text { (e.g. maximum distance of } 25 \mathrm{~km} \\
\text { between hospitals) } \\
\text { - Homogeneity of group services must } \\
\text { be guaranteed within two years after } \\
\text { signing the group contract }\end{array}$ \\
\hline $\begin{array}{l}\text { Hospital } \\
\text { association }\end{array}$ & $\begin{array}{l}\text { - Creation of a new legal } \\
\text { entity } \\
\text { - } \quad \text { or by contract }\end{array}$ & $\begin{array}{l}\text { Association committee: composed of } \\
\text { board members appointed by each } \\
\text { participating hospital. The } \\
\text { composition of the committee has to be } \\
\text { described in the association agreement. } \\
\text { - Common medical committee: } \\
\text { composed of physicians appointed by } \\
\text { the different medical councils of each } \\
\text { participating hospital (written } \\
\text { agreement between medical councils } \\
\text { of the participating hospitals). } \\
\text { Network committee: composed of the } \\
\text { members of the association committee } \\
\text { and the members of the common } \\
\text { medical committee. } \\
\text { General coordinator, medical } \\
\text { coordinator and nurse coordinator: } \\
\text { appointed by the association }\end{array}$ & $\begin{array}{l}\text { - All decisions should be discussed with } \\
\text { the medical council in each hospital } \\
\text { Unclear about the decision-making in } \\
\text { the board, unless described in the } \\
\text { statutes of the association }\end{array}$ & $\begin{array}{l}\text { - Specific requirements for an } \\
\text { 'association of a care area': (1) to } \\
\text { specialise or concentrate care; (2) } \\
\text { covering a minimum of } 150000 \\
\text { inhabitants; (3) participating is not } \\
\text { compulsory for all hospitals of the } \\
\text { territory concerned }\end{array}$ \\
\hline Hospital merger & $\begin{array}{l}\text { Legal entity may } \\
\text { disappear } \\
\text { - creation of another } \\
\text { legal entity }\end{array}$ & $\begin{array}{l}\text { Merger plan (one administrator, one } \\
\text { CEO, one CMO, one chief nursing } \\
\text { executive officer (CNO), one medical } \\
\text { council for all hospitals involved }\end{array}$ & $\begin{array}{l}\text { Board of the hospitals must ask their } \\
\text { medical council to give advice } \\
\text { concerning the merger plan, which is } \\
\text { non-binding }\end{array}$ & $\begin{array}{l}\text { - A hospital merger must comply with } \\
\text { several conditions to be authorised } \\
\text { (e.g. a maximum distance of } 30 \mathrm{~km} \\
\text { between hospitals) }\end{array}$ \\
\hline
\end{tabular}


- or absorption of an existing legal entity under

Must be submitted to the minister responsible for the authorisation

one single authorisation
- The merger plan must contain a minimum content related to the medical activity in het hospitals, as determined by act 
Table 2. Description of cases

Organization

Health system 1

Health system 2

Lead-organizationgoverned network 1

Lead organization-

governed network 2

Participant-governed network 1

Participant-governed network 2

\section{Description}

- A collaboration that provides health and social care to a large population. It consists of twenty-four facilities, two of which are hospitals.

- A not-for-profit association with one board for the collaboration, two hospital boards, executive management committees, and medical councils for each hospital.

- An intercommunal collaboration consisting of four hospitals with six hospital sites, as well as several psychiatric care facilities and facilities for older people.

- The governance structure consists of one board composed of politicians from a Belgian province and the municipalities. There are no boards at hospital level, only medical councils and executive management committees.

- A collaboration for the purposes of radiotherapy, oncology, and haematology. It consists of seven hospitals, with one hospital as the lead organization.

- A not-for-profit association and an association (cf. the Belgian Hospital Act) with a board and common medical committee.

- The main goal is to develop a sustainable knowledge network in which the joint optimization of the quality of care and the quality of management is ensured by sharing and valourizing the knowledge within the network. The network is a collaboration of 25 organizations.

- A not-for-profit association consisting of a board and a medical committee. It has several clinical and administrative working groups. The general assembly controls the board, which oversees the activities of the executive committee. One board member of the founding hospital of the collaboration participates in the board of each participating hospital (sometimes with voting rights, sometimes with an observer role).

- An emerging collaboration that aims to include four general hospitals. Its goal is to provide complex specialized services within the collaboration (e.g., cardiac surgery).

- There is an overarching board (with each hospital having one vote) and an executive committee, which is responsible for issues organized on a collaboration level. It has not yet been decided whether there should be a new medical committee on the collaboration level, or whether there should be a delegation of the existing medical councils.

- $\quad$ There are equal decision-making rights in the overarching board.

- The collaboration operates under an established framework agreement.

- There are three hospitals in the collaboration with equal decision-making rights. The goal of the collaboration is to enhance patient transfers and collaborations on certain care programs.

- Each hospital board and medical council of the participating hospitals decides on strategic decisions that might impact the individual hospitals' budgets. The strategic committee has ultimate responsibility for implementing the collaboration, but has no decision-making power over services that are still provided by the individual hospitals. The operational committee is responsible for effectively implementing the goals defined by the strategic committee and for achieving the objectives of the collaboration.

- $\quad$ There are equal decision-making rights in the strategic committee.

- Collaboration under an established framework agreement. 
Table 3. Facilitators and barriers

\begin{tabular}{|c|c|c|c|c|c|c|}
\hline & Health system 1 & Health system 2 & $\begin{array}{l}\text { Lead-organization- } \\
\text { governed network } 1\end{array}$ & $\begin{array}{l}\text { Lead-organization- } \\
\text { governed network } 2\end{array}$ & $\begin{array}{l}\text { Participant-governed } \\
\text { network } 2\end{array}$ & $\begin{array}{l}\text { Participant-governed } \\
\text { network } 1\end{array}$ \\
\hline Facilitators & $\begin{array}{l}\text { - Transmural, crossdomain } \\
\text { experience } \\
\text { - Resource-sharing and } \\
\text { supporting services } \\
\text { (logistics) } \\
\text { - A larger budget because of } \\
\text { the size and diversity of the } \\
\text { organization } \\
\text { - Central governance } \\
\text { - More time for strategy } \\
\text { - Well-known brand }\end{array}$ & $\begin{array}{l}\text { - Transmural, } \\
\text { crossdomain } \\
\text { experience } \\
\text { - Resource sharing and } \\
\text { supporting services } \\
\text { (logistics) } \\
\text { - A larger budget } \\
\text { because of the size and } \\
\text { diversity of the } \\
\text { organization } \\
\text { - Central governance } \\
\text { More time for strategy } \\
\text { - Well-known brand }\end{array}$ & 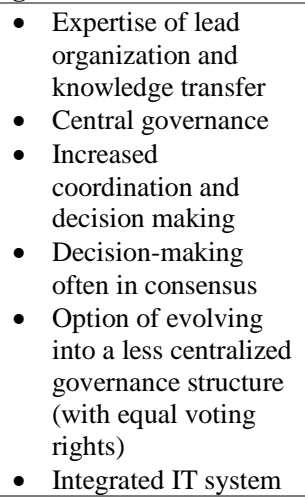 & 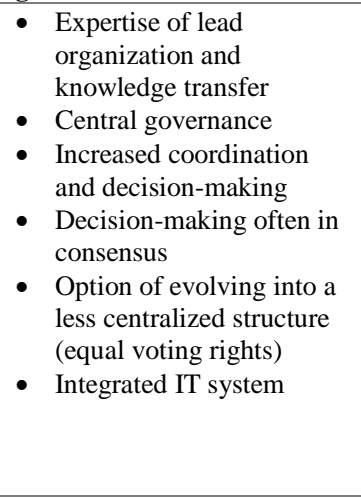 & $\begin{array}{l}\text { - High trust between partners } \\
\text { - } \text { Equal partnership } \\
\text { - Autonomy } \\
\text { - } \text { Bottom-up decision-making } \\
\text { - Alignment of the goals of } \\
\text { physicians and managers }\end{array}$ & $\begin{array}{l}\text { - High trust between partners } \\
\text { - Equal partnership } \\
\text { - Autonomy } \\
\text { - Bottom-up decision-making }\end{array}$ \\
\hline Barriers & $\begin{array}{l}\text { - Large scale sometimes } \\
\text { decreases effective decision- } \\
\text { making and efficiency } \\
\text { - Distance between hospitals } \\
\text { may complicate task } \\
\text { distribution } \\
\text { - Small hospitals feel less } \\
\text { involved in the decision- } \\
\text { making process } \\
\text { - Barrier to new organizations } \\
\text { entering this large } \\
\text { collaboration, since } \\
\text { governance is performed on } \\
\text { different levels and it is } \\
\text { difficult to leave the } \\
\text { collaboration } \\
\text { - Transfer of personnel to } \\
\text { other organizations is } \\
\text { difficult } \\
\text { - Complex financial structure } \\
\text { and legislation }\end{array}$ & $\begin{array}{l}\text { - Large scale sometimes } \\
\text { decreases effective } \\
\text { decision-making and } \\
\text { efficiency } \\
\text { - Distance between } \\
\text { hospitals may } \\
\text { complicate task } \\
\text { distribution } \\
\text { - Small hospitals feel } \\
\text { less involved in the } \\
\text { decision-making } \\
\text { process } \\
\text { - Difficult to collaborate } \\
\text { with hospitals outside } \\
\text { the health system } \\
\text { - Medical councils often } \\
\text { block decisions of the } \\
\text { board } \\
\text { - No alignment between } \\
\text { the goals of physicians } \\
\text { and management } \\
\text { - Complex financial } \\
\text { structure and legislation } \\
\text { - Still some competition } \\
\text { within the network }\end{array}$ & $\begin{array}{l}\text { The central position } \\
\text { of one lead } \\
\text { organization is } \\
\text { sometimes a barrier } \\
\text { to new organizations } \\
\text { joining the } \\
\text { collaboration } \\
\text { - Explicit approval of } \\
\text { each individual } \\
\text { hospital's medical } \\
\text { council is needed } \\
\text { - Transfer of personnel } \\
\text { to the collaboration } \\
\text { from the individual } \\
\text { organizations } \\
\text { - Physicians lose } \\
\text { voting rights by } \\
\text { working in different } \\
\text { collaborations } \\
\text { - Complex financial } \\
\text { structure and } \\
\text { legislation }\end{array}$ & $\begin{array}{l}\text { The central position of } \\
\text { the lead organization is } \\
\text { sometimes a barrier to } \\
\text { new organizations joining } \\
\text { the collaboration } \\
\text { - The size of the network is } \\
\text { a barrier to new hospitals } \\
\text { entering }\end{array}$ & $\begin{array}{l}\text { - Achieving agreement } \\
\text { between all partners takes a } \\
\text { long time, since they all } \\
\text { have the same voting right } \\
\text { - Complex governance } \\
\text { - Lack of agreement } \\
\text { - Physicians lose voting } \\
\text { rights by working in } \\
\text { different collaborations } \\
\text { - Transfer of personnel to } \\
\text { other organizations is } \\
\text { difficult } \\
\text { - Complex financial structure } \\
\text { and legislation } \\
\text { - Different deductions on } \\
\text { physicians fees }\end{array}$ & $\begin{array}{l}\text { - Achieving agreement } \\
\text { between all partners takes a } \\
\text { long time, since they all } \\
\text { have the same voting right } \\
\text { - Complex governance } \\
\text { - Lack of agreement } \\
\text { - Physicians lose voting } \\
\text { rights by working in } \\
\text { different collaborations } \\
\text { - Transfer of personnel to } \\
\text { another organization is } \\
\text { difficult } \\
\text { - Complex financial structure } \\
\text { and legislation } \\
\text { - Different deductions on } \\
\text { physicians fees }\end{array}$ \\
\hline
\end{tabular}

